\title{
Front Matter: Volume 9191
}

, "Front Matter: Volume 9191," Proc. SPIE 9191, Nonimaging Optics: Efficient Design for Illumination and Solar Concentration XI, 919101 (16 September 2014); doi: 10.1117/12.2085344

EDIE Event: SPIE Optical Engineering + Applications, 2014, San Diego, California, SPIE. United States 


\section{PROCEEDINGS OF SPIE}

\section{Nonimaging Optics: Efficient Design for Illumination and Solar Concentration XI}

Roland Winston

Jeffrey M. Gordon

Editors

17-18 and 20 August 2014

San Diego, California, United States

Sponsored and Published by

SPIE

Volume 9191 
The papers included in this volume were part of the technical conference cited on the cover and title page. Papers were selected and subject to review by the editors and conference program committee. Some conference presentations may not be available for publication. The papers published in these proceedings reflect the work and thoughts of the authors and are published herein as submitted. The publisher is not responsible for the validity of the information or for any outcomes resulting from reliance thereon.

Please use the following format to cite material from this book:

Author(s), "Title of Paper," in Nonimaging Optics: Efficient Design for Illumination and Solar Concentration XI, edited by Roland Winston, Jeffrey M. Gordon, Proceedings of SPIE Vol. 9191 (SPIE, Bellingham, WA, 2014) Article CID Number.

ISSN: 0277-786X

ISBN: 9781628412185

Published by

SPIE

P.O. Box 10, Bellingham, Washington 98227-0010 USA

Telephone +1 3606763290 (Pacific Time) · Fax +1 3606471445

SPIE.org

Copyright (C) 2014, Society of Photo-Optical Instrumentation Engineers.

Copying of material in this book for internal or personal use, or for the internal or personal use of specific clients, beyond the fair use provisions granted by the U.S. Copyright Law is authorized by SPIE subject to payment of copying fees. The Transactional Reporting Service base fee for this volume is $\$ 18.00$ per article (or portion thereof), which should be paid directly to the Copyright Clearance Center (CCC), 222 Rosewood Drive, Danvers, MA 01923. Payment may also be made electronically through CCC Online at copyright.com. Other copying for republication, resale, advertising or promotion, or any form of systematic or multiple reproduction of any material in this book is prohibited except with permission in writing from the publisher. The CCC fee code is 0277-786X/14/\$18.00.

Printed in the United States of America.

Publication of record for individual papers is online in the SPIE Digital Library.

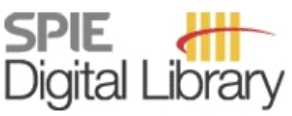

SPIEDigitalLibrary.org

Paper Numbering: Proceedings of SPIE follow an e-First publication model, with papers published first online and then in print and on CD-ROM. Papers are published as they are submitted and meet publication criteria. A unique, consistent, permanent citation identifier (CID) number is assigned to each article at the time of the first publication. Utilization of CIDs allows articles to be fully citable as soon as they are published online, and connects the same identifier to all online, print, and electronic versions of the publication. SPIE uses a six-digit CID article numbering system in which:

- The first four digits correspond to the SPIE volume number.

- The last two digits indicate publication order within the volume using a Base 36 numbering

system employing both numerals and letters. These two-number sets start with 00, 01, 02, 03, 04, $05,06,07,08,09,0 A, 0 B \ldots$. 0Z, followed by 10-1Z, 20-2Z, etc.

The CID Number appears on each page of the manuscript. The complete citation is used on the first page, and an abbreviated version on subsequent pages. Numbers in the index correspond to the last two digits of the six-digit CID Number. 


\title{
Contents
}

\author{
$\checkmark \quad$ Authors \\ vii Conference Committee \\ ix Introduction
}

\section{SESSION 1 FUNDAMENTAL OPTICS AND RADIATIVE TRANSFER}

919102 Conditions for perfect focusing multiple-point sources with the SMS design method (Invited Paper) [9191-1]

919103 Thermodynamic limit for coherence-limited solar power conversion [9191-2]

919104 Excitation of multiple surface-plasmon-polariton waves and waveguide modes in a 1D photonic crystal atop a 2D metal grating [9191-3]

\section{SESSION 2 ILLUMINATION OPTICS}

919105 Controlling light with freeform optics: recent progress in computational methods for optical design of freeform lenses with prescribed irradiance properties (Invited Paper) [9191-4]

919106 Tailoring free-form glass reflectors towards a homogeneous luminance distribution in roadway applications [9191-5]

\section{SESSION 3 NOVEL SOLAR AND LED OPTICS}

9191 OB Problems and challenges in nonimaging optics [9191-9]

$91910 C \quad$ Novel aplanatic designs for LED concentration [9191-10]

9191 OD Nonimaging optics heating up Mongolia's harsh winter [9191-11]

\section{SESSION 4 CONCENTRATOR PHOTOVOLTAICS}

9191 OE Switchable transparency optical element for reactive solar tracking (Invited Paper) [9191-12]

9191 OF Angular confinement in solar cells: viable micro-optical designs [9191-13]

9191 OG Decentralized nonimaging micro-optical concentrator [9191-14] 
91910 Optimization of a spectrum splitter using differential evolution algorithm for solar cell applications [9191-16]

\section{SESSION 6 DAYLIGHTING OPTICS}

9191 OK Light valve based on nonimaging optics with potential application in cold climate greenhouses [9191-19]

$9191 \mathrm{OL}$ Experimental study of direct transfer of concentrated solar radiation through optical fibres to high temperature thermal applications [9191-20]

$91910 \mathrm{M}$ Solar optical codes evaluation for modeling and analyzing complex solar receiver geometries [9191-21]

$91910 N \quad$ Light redirecting system using sine-wave based panels for dense urban areas [9191-22] 


\section{Authors}

Numbers in the index correspond to the last two digits of the six-digit citation identifier (CID) article numbering system used in Proceedings of SPIE. The first four digits reflect the volume number. Base 36 numbering is employed for the last two digits and indicates the order of articles within the volume. Numbers start with 00, 01, 02, 03, 04, 05, 06, 07, 08, 09, OA, OB...0Z, followed by 10-1Z, 20-2Z, etc.

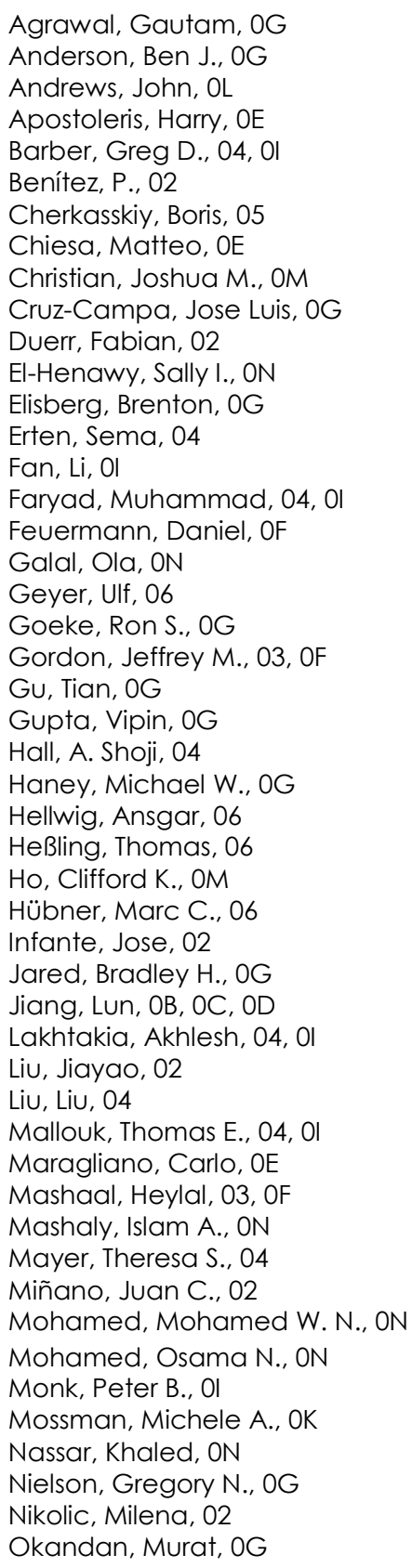

Oliker, Vladimir I., 05

Ortega, Jesus D., OM

Paap, Scott M., OG

Paßlick, Christian, 06

Rahou, Maryam, OL

Ricketts, Melissa, OC

Rosengarten, Gary, OL

Safwat, Amr M. E., ON

Stefancich, Marco, OE

Sweatt, William C., OG

Taha, Iman, ON

Valerio, Angel A., OK

Whitehead, Lorne A., OK

Widyolar, Bennett, OD

Winston, Roland, OB, OC, OD

Yellowhair, Julius, OM 
Proc. of SPIE Vol. $9191919101-6$

Downloaded From: https://www.spiedigitallibrary.org/conference-proceedings-of-spie on 26 Apr 2023 Terms of Use: https://www.spiedigitallibrary.org/terms-of-use 


\section{Conference Committee}

Program Track Chair

Ian T. Ferguson, The University of North Carolina at Charlotte

(United States)

Conference Chairs

Roland Winston, University of California, Merced (United States)

Jeffrey M. Gordon, Ben-Gurion University of the Negev (Israel)

Conference Program Committee

Pablo Benítez, Universidad Politécnica de Madrid (Spain) and Light

Prescriptions Innovators LLC (United States)

William J. Cassarly, Synopsys, Inc. (United States)

Daniel Feuermann, Ben-Gurion University of the Negev (Israel)

Juan Carlos Miñano, Universidad Politécnica de Madrid (Spain) and

Light Prescriptions Innovators LLC (United States)

Narkis E. Shatz, SAIC (United States)

\section{Session Chairs}

1 Fundamental Optics and Radiative Transfer

Roland Winston, University of California, Merced (United States)

2 Illumination Optics

Marco Stefancich, Masdar Institute of Science \& Technology

(United Arab Emirates)

3 Novel Solar and LED Optics

Jeffrey M. Gordon, Ben-Gurion University of the Negev (Israel)

4 Concentrator Photovoltaics

Narkis E. Shatz, SAIC (United States)

$5 \quad$ Luminescent and Holographic Optics

William J. Cassarly, Synopsys, Inc. (United States)

6 Daylighting Optics

Daniel Feuermann, Ben-Gurion University of the Negev (Israel) 
Proc. of SPIE Vol. $9191919101-8$

Downloaded From: https://www.spiedigitallibrary.org/conference-proceedings-of-spie on 26 Apr 2023 Terms of Use: https://www.spiedigitallibrary.org/terms-of-use 


\section{Introduction}

Welcome to our annual event in beautiful San Diego. While our conference has been going on for more than two decades, we should not take it for granted. Its continuity depends on the creativity of its participants (many of whom are in this room) and the vitality of the subject of nonimaging optics. On this point, you will see that the program has many innovative presentations. There is a nexus of nonimaging optics and energy that is very much "in the air". For example, concentrating photovoltaics at the nanoscale takes advantage of the efficiency of nonimaging optics at the diffraction limit.

I want to recognize Professor J. C. Minano, a pioneer in our field and the most recent recipient of the Optical Society of America Joseph Fraunhofer Award/Robert M. Burley prize. Let us hope this becomes a tradition. Finally, I want acknowledge our co-chair Professor Jeffrey M. Gordon, himself a distinguished contributor to our field, for his tireless efforts in putting together an exciting program.

Roland Winston Jeffrey M. Gordon 
Proc. of SPIE Vol. $9191919101-10$

Downloaded From: https://www.spiedigitallibrary.org/conference-proceedings-of-spie on 26 Apr 2023 Terms of Use: https://www.spiedigitallibrary.org/terms-of-use 